\title{
A reexamination of Yuknessia from the Cambrian of British Columbia and Utah
}

\author{
Steven T. LoDuca, ${ }^{1}$ Jean-Bernard Caron, ${ }^{2}$ James D. Schiffbauer, ${ }^{3}$ Shuhai Xiao, ${ }^{4}$ and Anthony Kramer $^{5}$ \\ ${ }^{1}$ Department of Geography and Geology, Eastern Michigan University, Ypsilanti, Michigan, 48197, USA 〈sloduca@emich.edu〉 \\ ${ }^{2}$ Department of Natural History (Palaeobiology), Royal Ontario Museum, 100 Queen's Park, Toronto ON M5S 2C6, Canada; University of \\ Toronto, Department of Ecology and Evolutionary Biology, 25 Willcocks Street, Toronto ON M5S 3B2, Canada; University of Toronto, \\ Department of Earth Sciences, 25 Russell Street, Toronto, Ontario, M5S 3B1, Canada 〈jcaron@ @rom.on.ca) \\ ${ }^{3}$ Department of Geological Sciences, University of Missouri, Columbia Missouri 65211, USA 〈schiffbauerj@missouri.edu〉 \\ ${ }^{4}$ Department of Geosciences, Virginia Tech, Blacksburg Virginia 24061, USA 〈xiao@vt.edu〉 \\ ${ }^{5}$ Department of Geology, University of Cincinnati, Cincinnati Ohio 45221, USA 〈isotelus@hotmail.com〉
}

\begin{abstract}
To investigate the phylogenetic affinity of Yuknessia simplex Walcott, 1919, scanning electron microscopy was applied to the Burgess Shale (Cambrian Series 3, Stage 5) type material and to new material from the Trilobite Beds (Yoho National Park) and specimens from the Cambrian of Utah. On the basis of fine-scale details observed using this approach, including banding structure interpreted as fusellae, Yuknessia Walcott, 1919 is transferred from the algae, where it resided for nearly a century, to the extant taxon Pterobranchia (Phylum Hemichordata). Considered as such, Yuknessia specimens from the Trilobite Beds and Spence Formation (Utah) are amongst the oldest known colonial pterobranchs. Two morphs regarded herein as two different species are recognized from the Trilobite Beds based on tubarium morphology. Yuknessia simplex has slender erect tubes whereas Yuknessia stephenensis n. sp., which is also known in Utah, has more robust erect tubes. The two paratypes of $Y$. simplex designated by Walcott (1919) are formally removed from Yuknessia and are reinterpreted respectively as an indeterminate alga and Dalyia racemata Walcott, 1919, a putative red alga.
\end{abstract}

\section{Introduction}

Charles Walcott erected Yuknessia as a monotypic genus in a 1919 report devoted to the algal component of the Burgess Shale biota, assigning it with some doubt to the Chlorophyta. In addition to the Trilobite Beds and Phyllopod Bed material described by Walcott (1919), the taxon has been reported from a number of other Cambrian Lagerstätten, including the Spence, Wheeler, and Marjum formations of Utah (Satterthwait, 1976; Conway Morris and Robison, 1988), Kinzers Formation of Pennsylvania (Skinner, 2005), and Yanjiahe, Niutitang, Yu'anshan (Chengjiang Biota), Balang, Kaili, and Huaqiao formations of China (Chen and Erdtmann, 1991; Chen et al., 1996; Hou et al., 1999; Yang et al., 1999, 2003; Babcock and Zhang, 2001; Yang, 2006; Fu et al., 2010; Guo et al., 2010; Babcock et al., 2011; Zhao et al., 2005, 2011). In each case, Walcott's algal interpretation was followed. Recently, however, Maletz et al. (2005) cast doubt on an algal affinity for Yuknessia. In that study, using scanning electron microscopy (SEM) in backscattered electron (BSE) mode, fusellar structure was documented in a Wheeler Shale specimen for which the gross morphology "resembles in colony habitus the thalli of the alga Yuknessia simplex" (Maletz et al., 2005, p. 84). The specimen was formally described as a cephalodiscid hemichordate, and it was remarked that "It is very probable that more pterobranch colonies will be discovered at a closer inspection of those algae" (Maletz et al., 2005, p. 84).

The present study, initiated as part of a broad-scale effort to develop a more complete and better resolved picture of macroalgae in the Cambrian biosphere, provides a detailed reexamination of Yuknessia, focusing on Walcott's type material but also including new specimens collected from the Trilobite Beds by the Royal Ontario Museum and specimens previously assigned to the genus from the Cambrian of Utah. New, fine-scale details observed for these specimens, primarily through SEM-based studies, indicate that Yuknessia is a benthic colonial pterobranch.

\section{Material and methods}

The Yuknessia simplex type material comprises the holotype, USNM 35406, from the Trilobite Beds on Mount Stephen (locality 14s of Walcott), and two paratypes, USNM 35407 and 35408 , both from the slightly younger Phyllopod Bed interval of the Burgess Shale Formation at the Walcott Quarry site (locality 35k of Walcott) (Fletcher and Collins, 1998). All three specimens were examined in detail. Among the 18 additional Burgess Shale USNM specimens cataloged as Yuknessia, all of which are fragmentary and from the Phyllopod Bed, 194093 and 194098 were selected for in-depth investigation. Four new specimens from the Trilobite Beds, ROM 62918-62921, and 
eight specimens from Utah were also examined. Among the latter, KUMIP 204380 from the Wheeler Shale in the Drum Mountains, KUMIP 147909 and KUMIP 204382 from the Wheeler Shale in the House Range, and KUMIP 204381 from the Spence Shale in the Wellsville Mountains were illustrated and formally assigned to $Y$. simplex by Conway Morris and Robison (1988). The other Utah specimens examined comprise KUMIP 314270 from the Spence Shale in the Wellsville Mountains, KUMIP 314068 from the Wheeler Shale, Drum Mountains, and two newly collected specimens, FMNH PE 61080 and FMNH PE 61081, from the Pierson Cove Formation and underlying Wheeler Shale, respectively, in the Drum Mountains. A Burgess Shale specimen of Dalyia racemata Walcott, 1919 (USNM 35416; from the Phyllopod Bed) was examined in detail for comparative purposes. Repository abbreviations are as follows: USNM, Smithsonian Institution National Museum of Natural History, Washington D.C., USA; ROM, Royal Ontario Museum (Invertebrate Palaeontology collections), Toronto, Canada; KUMIP, Biodiversity Institute, University of Kansas, Lawrence, USA; FMNH, Field Museum of Natural History, Chicago, USA; WHE, Technische Universität Berlin collection, Berlin, Germany.

All examined specimens comprise flattened material embedded in the matrix and exposed on bedding plane surfaces. No attempts were made to obtain isolated material from these specimens.

SEM study of Yuknessia and Dalyia type material, excluding USNM 35407, was conducted at the Smithsonian Institution using a Philips XL-30. Specimen USNM 35407, together with USNM 194093, 194098, and most of the Utah material, was examined on a Hitachi S-3200N at the Electron Microbeam Analysis Laboratory, Department of Earth and Environmental Science, University of Michigan. Specimens ROM 62918-62921 were examined at the University of Toronto on a JEOL JSM6610-LV, and specimens KUMIP 314270 and 314068 were examined at the Virginia Tech Nanoscale Characterization and Fabrication Laboratory and the University of Missouri Electron Microscopy Core using FEI Quanta 600F SEMs. All specimens were examined uncoated under low vacuum, and BSE images were obtained using accelerating voltages of $15-30 \mathrm{keV}$. All energy dispersive X-ray spectroscopic (EDS) analyses (Virginia Tech and University of Missouri) were conducted using identical operating conditions: 13.1-12.1 mm working distances (variability due to $\mathrm{mm}$-scale relief of fossil slabs), $20 \mathrm{keV}$ beam accelerating voltage, and a large beam spot (5.0) for high X-ray signal generation. EDS points were randomly positioned, yielding a total of 58 host rock and 83 fossil point analyses. The resulting data (reported in normalized weight percent) were averaged by position (matrix vs. fossil) across each specimen.

\section{Systematic paleontology}

Phylum Hemichordata Bateson, 1885

Class Pterobranchia Lankester, 1877

Genus Yuknessia Walcott, 1919

Type species._Yuknessia simplex Walcott, 1919, by monotypy.

Diagnosis.-Tubaria comprising radiating clusters of erect tubes branching from a small network of repent tubes. Repent tubes irregularly branching, $\sim 0.3 \mathrm{~mm}$ wide; erect tubes mostly isolated along their length, typically from 6 to $20 \mathrm{~mm}$ in length and widening gradually distally from $\sim 0.1 \mathrm{~mm}$ at the base to $0.4-1 \mathrm{~mm}$ at the aperture; aperture simple and straight. Branching of repent tubes through resorption or perforation of fusellar tissue in parent tube. Branching of erect tubes occurs sporadically. Tubes composed of fusellar bands, mostly irregularly arranged. Fusellar heights range from 0.018 to $0.064 \mathrm{~mm}$. No sclerotized stolon sheath present.

Remarks.-Based on the new details revealed by BSE imaging and comparative study, the type species for Yuknessia, Y. simplex, is redescribed herein as a benthic colonial pterobranch. The genus diagnosis is emended accordingly and accommodates a new species, $Y$. stephenensis $\mathrm{n}$. sp. The $Y$. stephenensis holotype is from the Trilobite Beds and all material previously assigned to $Y$. simplex from the Spence and Wheeler formations of Utah by Conway Morris and Robison (1988) is referred to this new species. The diagnosis for the repent part of the tubarium for Yuknessia was developed entirely from Utah material of $Y$. stephenensis as none of the examined specimens of $Y$. simplex provide a good view of this area.

Yuknessia simplex Walcott, 1919

Figures 1.1-1.4, 2.4-2.9

Diagnosis.-Yuknessid pterobranch with erect tubes typically from 5 to $10 \mathrm{~mm}$ in length and widening gradually distally from $\sim 0.1 \mathrm{~mm}$ at the base to a maximum of $0.5 \mathrm{~mm}$ at the aperture.

Description.-Tubarium of holotype comprises numerous elongate conical tubes arrayed in roughly radial fashion and emerging around a black granular object preserved in positive relief (Fig. 1.1, 1.2). Tubes preserved as thin flat films lacking obvious evidence of folding or wrinkling, and setting apart from the surrounding shale by their smoother texture, glossy to submetallic luster, and darker brown color. Tube form slightly flexuous; definitive branching not evident but overlaps present (Fig. 1.3). Length mainly in the range of 6 to $8 \mathrm{~mm}$; some as short as $4 \mathrm{~mm}$, the longest reaching $13 \mathrm{~mm}$. Tube width gradually increasing distally from approximately $0.1 \mathrm{~mm}$ in the proximal area to $0.4 \mathrm{~mm}$ at mid-length and $0.5 \mathrm{~mm}$ at the aperture (Table 1). Apertures simple, without an obvious lip or ornamentation. Fusellae with an average height of $0.022 \mathrm{~mm}$ $(\mathrm{SD}=0.004 \mathrm{~mm} ; \mathrm{N}=7)$ faintly visible in BSE images (Fig. 1.4).

Tubaria for ROM 62919-62921 similar to holotype in terms of tube dimensions and fusellar arrangement (Table 1; Fig. 2.4-2.9). For 62919, BSE images show clear fusellae with strong transverse ridges and definitive branching for tubes (Fig. 2.6, 2.7); like the holotype specimen, a granular structure is present at the center of the tubarium (Fig. 2.5). Tubaria for 62920 and 62921 more expansive than holotype and 62919, comprising greater numbers of zooidal tubes (Fig. 2.8, 2.9). All examined specimens lack an evident stolon system.

Holotype.-USNM 35406 (Fig. 1.1-1.4).

Other material.-ROM 62919-62921. 

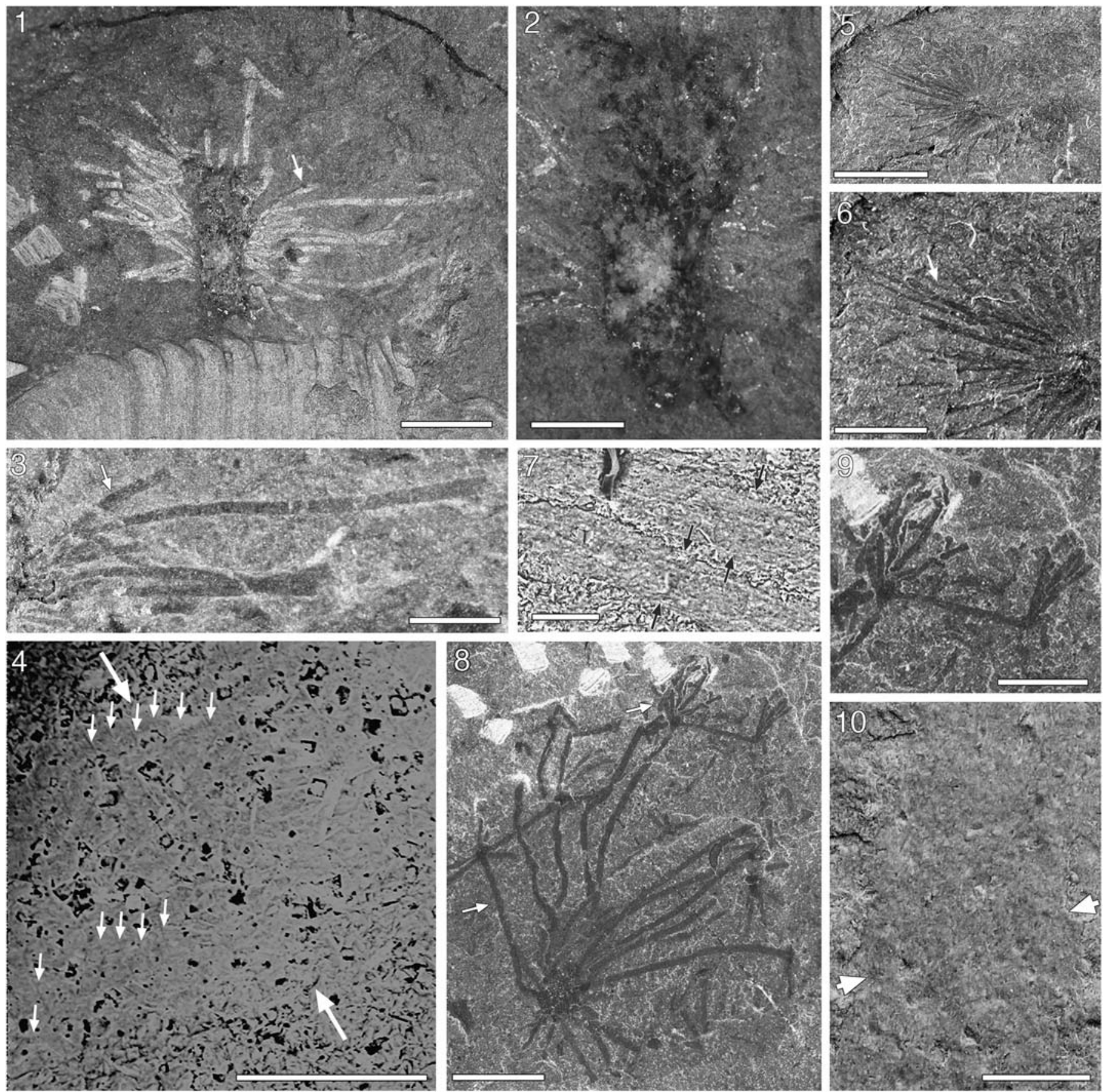

Figure 1. Specimens originally designated as holotype and paratypes of Yuknessia simplex. (1-4), holotype of Yuknessia simplex Walcott, 1919, Trilobite Beds, Burgess Shale Formation, Mount Stephen (locality 14s of Walcott), British Columbia (USNM 35406): (1), the entire specimen in direct light and immersed in water, trilobite exoskeleton at bottom; (2), detail of central area in 1 showing tubes emerging along a foreign object of uncertain affinity, specimen immersed in water, polarized light; (3), detail of tubes at arrow in 1, dry, direct light; (4), BSE image of tube marked by arrow in 3, large opposing arrows mark sides of tube, small arrows mark transverse striations. (5-7), indeterminate alga, specimen originally assigned by Walcott (1919) as a paratype of $Y$. simplex, Phyllopod Bed, Burgess Shale Formation, Walcott Quarry (locality 35k of Walcott), British Columbia (USNM 35407): (5), the entire specimen, dry, direct light; (6), detail of elongate elements showing distal tapering, dry, direct light; (7), BSE image of elongate elements at arrow in 6, opposing arrows mark sides of an individual element. (8-10), Dalyia racemata Walcott, specimen originally assigned by Walcott (1919) as a paratype of Y. simplex, Phyllopod Bed, Burgess Shale Formation, Walcott Quarry (locality 35k of Walcott), British Columbia (USNM 35408): (8), the entire specimen, dry, polarized light; (9), detail of area marked by upper arrow in $\mathbf{8}$ showing branching pattern, dry, polarized light; (10), BSE image of stipe marked by lower arrow in 8, opposing arrows mark sides of stipe. Scale bars: $\mathbf{1}, \mathbf{5}, \mathbf{8}, 5 \mathrm{~mm} ; \mathbf{2}, 2 \mathrm{~mm} ; \mathbf{3}, \mathbf{6}, \mathbf{9}, 2.5 \mathrm{~mm} ; \mathbf{4}, \mathbf{1 0}, 0.2 \mathrm{~mm} ; \mathbf{7}, 0.1 \mathrm{~mm}$.

Occurrence.-Trilobite Beds, Campsite Cliff Shale Member, Burgess Shale Formation, Mount Stephen, British Columbia (locality 14s of Walcott); Cambrian Series 3, Stage 5.
Remarks.-The faint transverse banding visible on the tubes of the $Y$. simplex holotype in BSE images has not been noted previously and is not evident in reflected light. Similar banding, but 
more evident, is present on the new Trilobite Beds specimens assigned herein to $Y$. simplex, which also compare closely with the holotype in terms of tube dimensions. Arrangement and spacing for the banding are in agreement with fusellar structure documented for several Cambrian pterobranchs, as are general form and organization for the colony (see Comparisons). On the basis of these findings, $Y$. simplex is transferred to the Pterobranchia and provided with an emended diagnosis.

At the center of the holotype is an object approximately $8 \mathrm{~mm}$ long and $3 \mathrm{~mm}$ wide at its widest point that appears darker than the surrounding shale when wet and has a nonhomogeneous and granular surface, without pores or other openings other than a shallow cavity in the center, the inner portion of which is occupied by rust-colored crystals. This object was described by Walcott (1919) as the "main stem" of Yuknessia, but is herein regarded to be biologically unrelated to the surrounding tubes. It does not show the conical plates described by Walcott (1919) and interpreted by him as forming the bases of the tubes; instead, the tubes appear to emerge along its margin. The style of preservation for this object also differs conspicuously from the surrounding tubes and both the texture and color differ from associated trilobite material on the same bedding plane (Fig. 1.1), suggesting it might be inorganic. A similar but smaller structure, also with a granular texture, is present at the center of ROM 62919. Based on these observations, these colonies are interpreted to have begun development attached to foreign objects presumably recrystallized during later diagenesis. Such a habit is reminiscent of living benthic pterobranch colonies (Stebbing, 1970), which commonly attach to the undersides of empty bivalve shells.

Restudy of Walcott's paratypes of $Y$. simplex (USNM 35407 and USNM 35408) does not support a pterobranch affinity for this material, and these specimens are herein formally removed from Yuknessia (see below). For the two non-type specimens from the USNM collection selected for detailed study (194093 and 194098), transverse banding is not evident in BSE images, the surfaces instead appearing structureless and similar to 35408 . On this basis, these specimens, too, are rejected as yuknessids. Width dimensions for this material are consistent with a Dalyia racemata affinity, but the material is too fragmentary to allow definitive assignment to this taxon. Surficial examination of the remainder of the USNM material and all ROM material previously attributed to $Y$. simplex suggests a Dalyia affinity as well. Thus, no definitive examples of $Y$. simplex are known from the Walcott Quarry and it should, therefore, be excluded from the Greater Phyllopod Bed community (Caron and Jackson, 2006, 2008) in future studies.

Yuknessia stephenensis new species

Figures 2.1-2.3, 3.1-3.4, 4.1-4.6, 5.1-5.10

Diagnosis.-Yuknessid pterobranch with erect tubes typically from 7 to $20 \mathrm{~mm}$ in length and widening gradually distally from $\sim 0.1 \mathrm{~mm}$ at the base to $0.7-1 \mathrm{~mm}$ at the aperture.

Description.-Tubarium for holotype comprises numerous elongate conical tubes arrayed in radial fashion and extending from a small central area, details for which are concealed by a dense array of overlapping tubes (Fig. 2.1, 2.3). Erect tubes preserved flattened, lacking obvious folding or wrinkling and setting apart from the surrounding shale by their smoother texture and glossy to submetallic luster. Tube form slightly flexuous; definitive branching not evident but overlaps present (Fig. 2.3). Length mainly in the range of 6 to $7 \mathrm{~mm}$, the longest reaching $8 \mathrm{~mm}$. Tube width gradually increasing distally from approximately $0.1 \mathrm{~mm}$ in the proximal area to $0.4 \mathrm{~mm}$ at midlength and $0.8 \mathrm{~mm}$ at the aperture (Table 1). Apertures simple, without an obvious lip or ornamentation. Fusellar banding and occasional oblique sutures evident in BSE images (Fig. 2.2). Fusellae with an average height of $0.032 \mathrm{~mm}(\mathrm{SD}=0.003 \mathrm{~mm}$; $\mathrm{N}=7$ ). No stolon structure evident.

Tubarium for KUMIP 204380 comprises numerous erect tubes arranged in roughly radial fashion, emerging from a small repent area (Fig. 3.1). All tubes largely flattened; most areas with a glossy to submetallic luster, the glossy areas in places being translucent. Repent portion comprising a main tube $\sim 0.3 \mathrm{~mm}$ in diameter which gives rise at irregular distances to secondary repent tubes of similar diameter, these in most cases turning abruptly to run parallel to the parent tube beyond the point of budding (Fig. 3.3, 3.4). All show well-developed fusellae with fusellar heights of 0.025 to $0.04 \mathrm{~mm}$ in BSE images (Fig. 3.4); these also visible, to a lesser extent, in reflected light. Fusellae of main tube undeformed at junctions with secondary repent tubes (Fig. 3.4). No evidence for diaphragms within the individual tubes. Erect tubes mostly isolated along their length; most with a length of 10 to $11 \mathrm{~mm}$, the shortest $7 \mathrm{~mm}$, the longest reaching $12 \mathrm{~mm}$. Width gradually increasing distally from $\sim 0.1 \mathrm{~mm}$ at the base to $\sim 1 \mathrm{~mm}$ at the aperture (Table 1). Aperture simple, straight, without obvious ornamentation. Erect tubes branch from repent tubes in the same manner that secondary repent tubes branch from the parent repent tube, but diverging at an angle rather than running parallel. Proximal parts of adjacent erect tubes in some cases in contact (adnate) before diverging to form a Y-shaped pair (Fig. 3.2). Erect tube arrangement in places suggestive of branching (Fig. 3.1), but definitive evidence for branching lacking. Erect tubes show well-developed fusellae along their entire length (Fig. 3.2); fusellar heights vary between 0.02 and $0.05 \mathrm{~mm}$. No stolon structure or zooids evident.

Tubaria for other Utah specimens similar to 204380 with regard to erect tubes (Table 1; Figs. 4, 5), but those for KUMIP 204381 and KUMIP 314270 from the Spence Shale, with maximum lengths of 30 and $24 \mathrm{~mm}$ respectively, somewhat longer (Fig. 5.1, 5.7). For both Spence Shale specimens, branching of tubes is evident (Fig. 5.2, 5.7). Erect tubes for KUMIP 17909 and FMNH PE 61081 show occasional oblique sutures in BSE images (Fig. 4.2, 4.6). Wheeler Shale specimen KUMIP 204382 shows strong transverse ridges in negative relief (as an external mold or interior view of the specimen) associated with fusellae (Fig. 4.3).

Etymology.-From Mount Stephen, a mountain located near the town of Field in Yoho National Park, British Columbia.

Holotype.-ROM 62918 (Fig. 2.1-2.3), from the Trilobite Beds, Campsite Cliff Shale Member, Burgess Shale Formation on Mount Stephen, British Columbia (locality 14s of Walcott); Cambrian Series 3, Stage 5. 


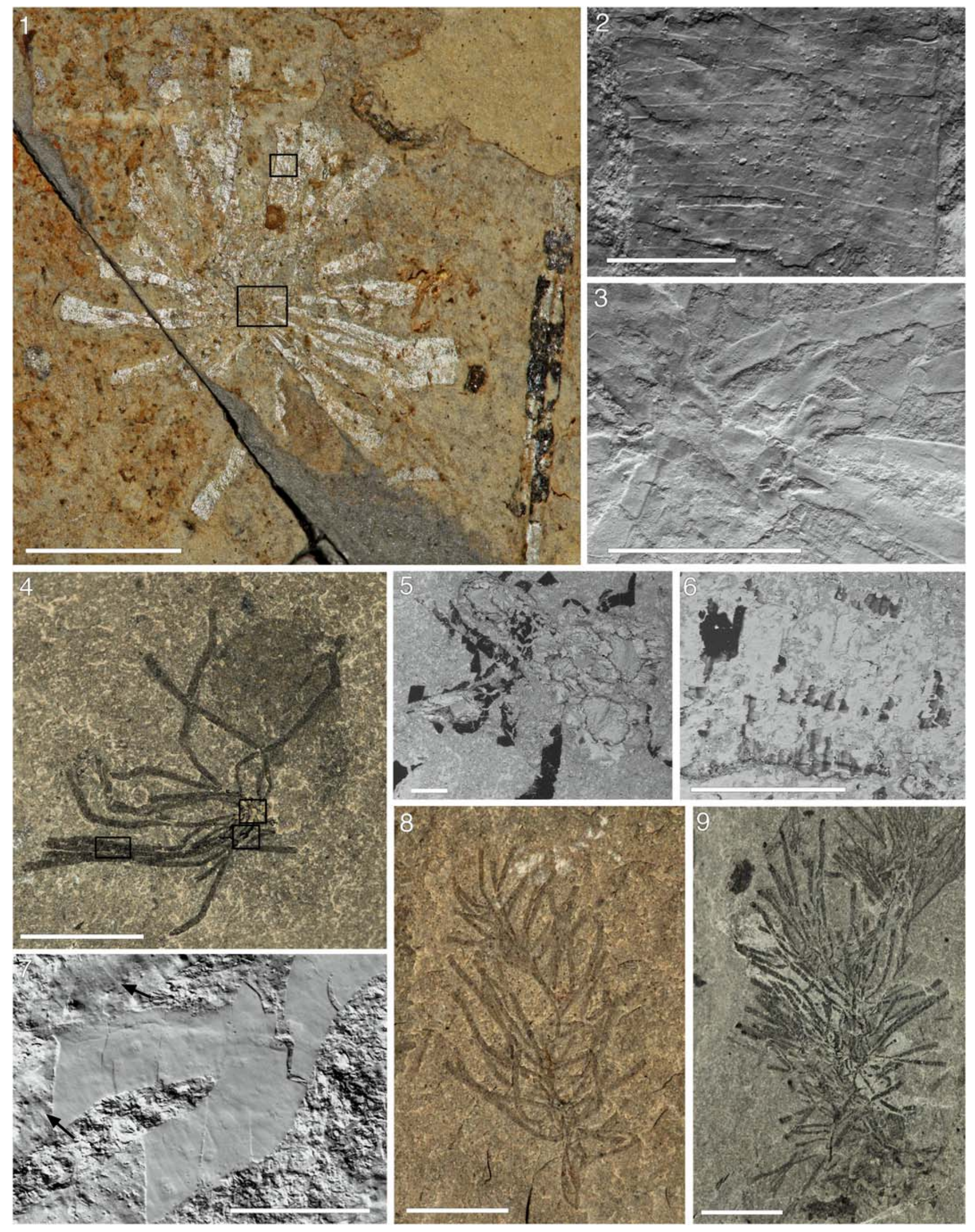


Table 1. Morphometric data (in $\mathrm{mm}$ ) for erect tubes of specimens regarded herein as belonging to Yuknessia

\begin{tabular}{|c|c|c|c|c|c|c|c|}
\hline Specimen & Formation & Locality & Length (average) & $\begin{array}{c}\text { Length } \\
\text { (maximum) }\end{array}$ & $\begin{array}{l}\text { Width at Mid- } \\
\text { Length (average) }\end{array}$ & $\begin{array}{l}\text { Width at Aperture } \\
\text { (average) }\end{array}$ & $\begin{array}{l}\text { Fusellar Height } \\
\text { (average) }\end{array}$ \\
\hline USNM 35406 & Burgess Shale & Trilobite Beds & 7 & 13 & 0.40 & 0.50 & 0.022 \\
\hline ROM $62919^{1}$ & Burgess Shale & Trilobite Beds & 8 & 9.5 & 0.30 & 0.50 & 0.029 \\
\hline ROM $62920^{1}$ & Burgess Shale & Trilobite Beds & 7 & 8 & 0.30 & 0.45 & 0.018 \\
\hline ROM $62921^{1}$ & Burgess Shale & Trilobite Beds & 6 & 7 & 0.26 & 0.40 & - \\
\hline ROM $62918^{1}$ & Burgess Shale & Trilobite Beds & 6 & 8 & 0.40 & 0.80 & 0.032 \\
\hline FMNH PE 61082 & Wheeler & Drum Mts & 7 & 10 & 0.40 & 0.70 & 0.025 \\
\hline KUMIP $204380^{2}$ & Wheeler & Drum Mts & 10 & 11 & 0.50 & 0.80 & 0.035 \\
\hline KUMIP 314068 & Wheeler & Drum Mts & concealed & concealed & 0.60 & 0.75 & 0.031 \\
\hline FMNH PE 61081 & Wheeler & Drum Mts & 7 & 10 & 0.40 & 0.70 & 0.025 \\
\hline KUMIP $147909^{2}$ & Wheeler & House Range & 9 & 12 & 0.40 & 0.70 & 0.044 \\
\hline KUMIP $204382^{2}$ & Wheeler & House Range & 12 & 15 & 0.45 & 0.75 & 0.043 \\
\hline WHE 001 & Wheeler & House Range & 12 & 22 & 0.60 & 0.80 & 0.049 \\
\hline FMNH PE 61080 & Pierson Cove & Drum Mts & 10 & 13 & 0.50 & 0.80 & 0.034 \\
\hline KUMIP $204381^{2}$ & Spence & Wellsville Mts & 20 & 30 & 0.65 & 1.00 & 0.064 \\
\hline KUMIP 314270 & Spence & Wellsville Mts & 11 & 24 & 0.50 & 0.90 & 0.049 \\
\hline
\end{tabular}

${ }^{1}$ New specimens.

${ }^{2}$ Specimens illustrated in Conway Morris and Robison (1988).

Other material.-KUMIP specimens 147909, 204380, 204381, 204382, 314068, 314270; FMNH specimens PE 61080, PE 61081; WHE 001.

Occurrence.-Trilobite Beds, Campsite Cliff Shale Member, Burgess Shale Formation, Mount Stephen, British Columbia (locality 14s of Walcott) (Cambrian Series 3, Stage 5); Spence Shale, Wellsville Mountains, Utah (Cambrian Series 3, Stage 5); Wheeler Shale, Drum Mountains and House Range, Utah (Drumian Stage); Pierson Cove Formation, Drum Mountains, Utah (Drumian Stage).

Remarks.-Trilobite Beds specimen ROM 62918 and all Utah Yuknessia specimens differ from the $Y$. simplex holotype and other specimens from the Trilobite Beds by the greater width of the erect tubes (aperture width of $0.7-1.0 \mathrm{~mm}$ vs. $0.4-0.5 \mathrm{~mm}$; Table 1). On this basis, a new species, Y. stephenensis, is erected to accommodate ROM 62918 and the Utah material. The Spence Shale specimens differ from the Wheeler Shale specimens in having somewhat longer erect tubes, but this is not considered a sufficiently great difference to warrant placement in a separate species.

The repent part of the tubarium for $Y$. stephenensis is known in some detail only for KUMIP 204380 (Fig. 3). For the other specimens examined, this part of the tubarium is largely or entirely concealed as a consequence of erect tubes that have draped over this area during burial, preservation of the colony in lateral view, or overlying matrix. For 204380, despite providing a good view of the repent area, a definite prosicula is not known. Many of the secondary repent tubes for this specimen originate at close-spaced distances along the central part of the primary repent tube, and this may be considered as being close to the point of origin for the colony. The undistorted nature of the fusellae where a new tube emerges is consistent with branching accomplished through resorption or perforation of the tube wall. Unlike specimens of $Y$. simplex, there is no evidence to suggest that the repent part of this specimen was attached to a foreign object, and the same applies to all other specimens of Y. stephenensis.

For several of the specimens assigned to $Y$. stephenensis, including 204380, the zooidal tubes are preserved at multiple levels in the silt layers. This supports the inference that the tubes were originally erect and were subsequently brought down near the level of the repent area as a consequence of burial and diagenetic compression.

Because isolated material was not available for study, it cannot be determined with certainty whether the fusellae of either the erect tubes or repent area are full rings or half rings. The scarcity of visible sutures, however, is suggestive of the former. Enough of the tube wall can be observed for the repent area of 204380, however, to conclude that this part of the tubarium lacks a zig-zag suture pattern.

Conway Morris and Robison (1988, fig. 11.1), in addition to the material examined herein, assigned to Yuknessia simple tubular forms from the Marjum Formation in the House Range, which they regarded as fragmentary remains. Handle and Powell (2012), however, documented marked differences in chemical composition and microstructure between similar tubular material from the Wheeler Shale and Yuknessia, the tubular forms found to have a purely kerogeneous composition, and concluded that this material did not represent Yuknessia. In the present study, no evidence of fusellar structure was detected among a collection of these tubular forms from the Marjum Formation examined with BSE imaging, and detailed 

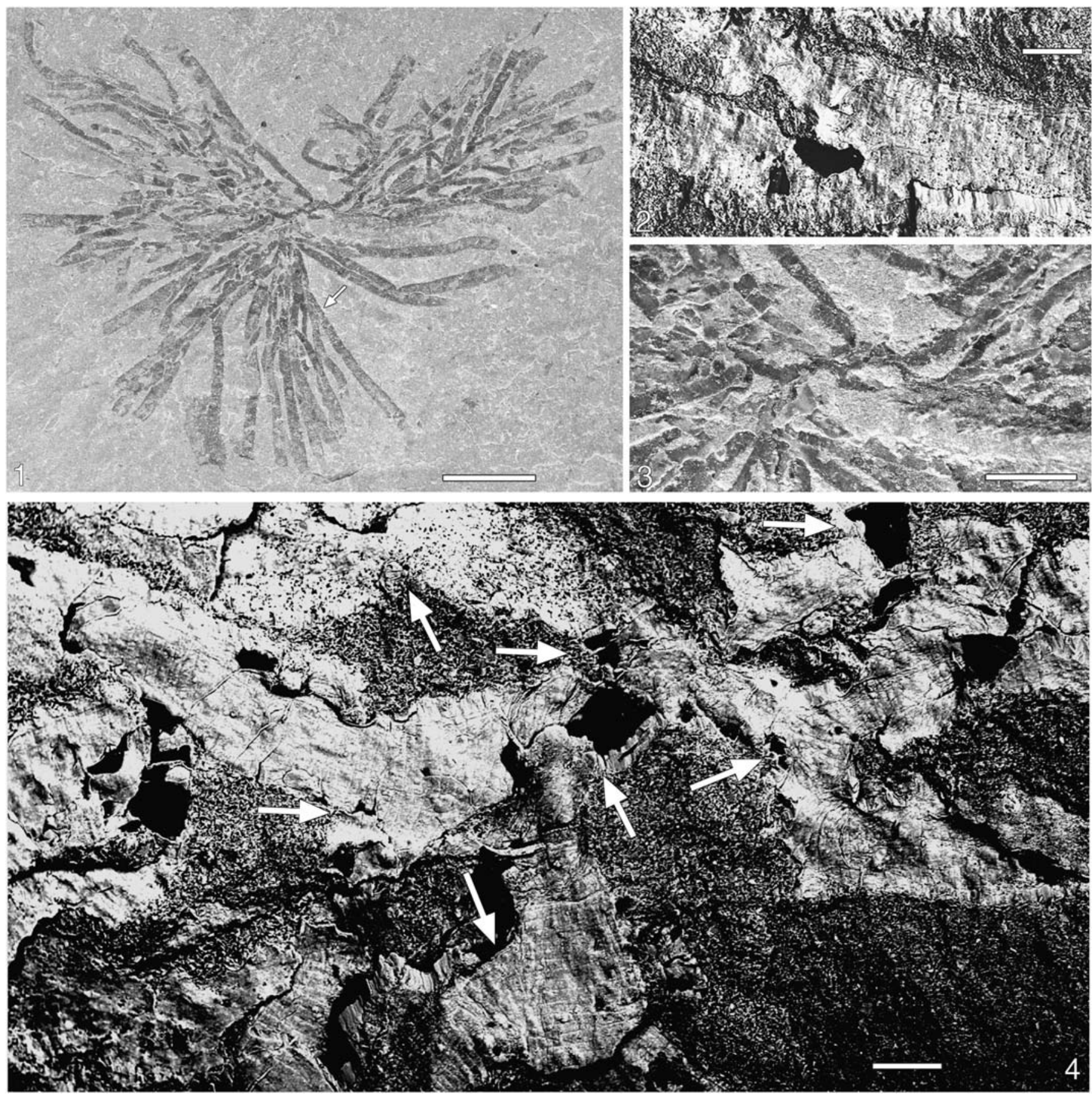

Figure 3. Yuknessia stephenensis n. sp., Wheeler Shale, Drum Mountains, Utah (KUMIP 204380): (1), entire specimen; (2), BSE image of area marked by arrow in 1 showing two erect tubes with fusellar structure and adnate lower portions; (3), central portion of tubarium showing repent tubes; (4), BSE image of central portion of tubarium showing fusellar structure and branching details for repent tubes, arrows marking branch points. All non-BSE images show dry specimens in direct light. Scale bars: $1,5 \mathrm{~mm} ; \mathbf{2}, \mathbf{4}, 0.2 \mathrm{~mm} ; \mathbf{3}, 2 \mathrm{~mm}$

measurements indicate that they also differ from the erect tubes of Yuknessia in lacking a tapered form. On the basis of these observations, together with the Handle and Powell (2012) findings, this material is regarded herein to be taxonomically distinct from Yuknessia, the available evidence being consistent with an algal affinity.

The single specimen (WHE 001) described from the Wheeler Shale (House Range) by Maletz et al. (2005) as
?Cephalodiscus sp. has tube dimensions and details of fusellar structure that match those for the Wheeler Shale specimens assigned herein to Y. stephenensis, particularly KUMIP 204382 (Table 1). The basal part of this specimen is not preserved, as noted by Maletz et al. (2005), but because all of the observed features match those for the other Utah specimens, including possible branching of the tubes, it is regarded herein as a further example of $Y$. stephenensis. 

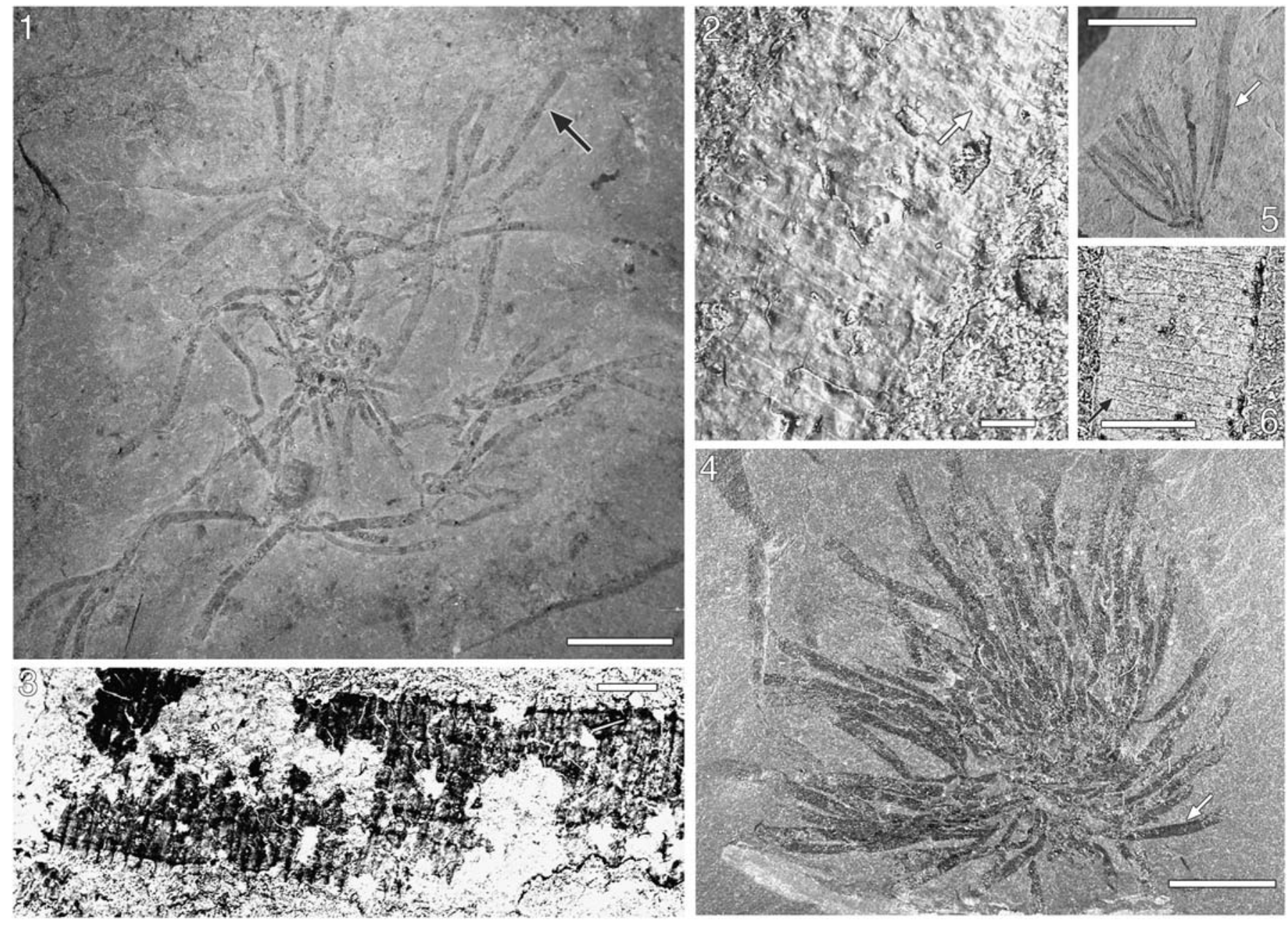

Figure 4. Yuknessia stephenensis n. sp. from the Wheeler Shale, Utah: (1), KUMIP 17909, entire specimen, House Range; (2), BSE image of erect tube marked by arrow in 1 showing fusellar structure, with arrow marking oblique suture; (3), KUMIP 204382, BSE image of erect tube marked by arrow in 4 showing fusellae with strong transverse ridges in negative relief; (4), KUMIP 204382, entire specimen, House Range; (5), FMNH PE 61081, entire specimen, Drum Mountains; (6), BSE image of erect tube at arrow in $\mathbf{5}$ showing fusellar structure, with arrow marking oblique suture. All non-BSE images show dry specimens in direct light. Scale bars: $\mathbf{1}, \mathbf{4}, \mathbf{5}, 5 \mathrm{~mm} ; \mathbf{2}, 0.1 \mathrm{~mm}, \mathbf{3}, \mathbf{6}, 0.2 \mathrm{~mm}$.

?Division Rhodophyta

Genus Dalyia Walcott, 1919

Type species.—Dalyia racemata Walcott, 1919, as designated by Walcott (1919).

Dalyia racemata Walcott, 1919

Figure 1.8-1.10

\section{Material.—USNM 35408.}

Description.-Thallus for USNM 35408 comprises some 13 elongate cylindrical stipes that diverge upward from a common bulbous base (holdfast?), this being slightly raised and darker than the surrounding shale, and measuring approximately $2 \mathrm{~mm}$ by $3 \mathrm{~mm}$ (Fig. 1.8). Each stipe flattened, darker black and smoother than surrounding shale, the longest reaching a length of $16 \mathrm{~mm}$, most $9-12 \mathrm{~mm}$; average stipe width $0.4 \mathrm{~mm}$ ( $\mathrm{SD}=0.026 \mathrm{~mm}, \mathrm{~N}=10$ ), width constant along length. Several stipes branch terminally to form a whorl comprising five to seven elements, the precise number difficult to determine owing to the flattened nature of the specimen. Elements within a whorl of cylindrical form, with a width of $0.25 \mathrm{~mm}$ and up to $4.3 \mathrm{~mm}$ in length; in one case, one of these elements branches terminally to form a further whorl comprising some four elements of cylindrical form, each $0.2 \mathrm{~mm}$ wide and $3 \mathrm{~mm}$ long, with terminations that appear slightly rounded (Fig. 1.9). Stipes structureless in BSE images, without transverse striations (Fig. 1.10).

Remarks.-In the original description of $Y$. simplex, Walcott (1919, p. 236) noted for the stipes: "there does not appear to be any terminal bifurcation, although on one specimen it is suggested by the presence of two whorls of terminal branchlets of Dalyia racemata (pl. 56)". This statement seems to refer to USNM 35408 (the three specimens that comprise the type material were not described separately), and Walcott's explanation was to suggest that Yuknessia and Dalyia might have been preserved together on the same slab. Walcott heavily retouched his photographs with a pencil, and in his illustration of 35408 (fig. 1c, plate 54) this 

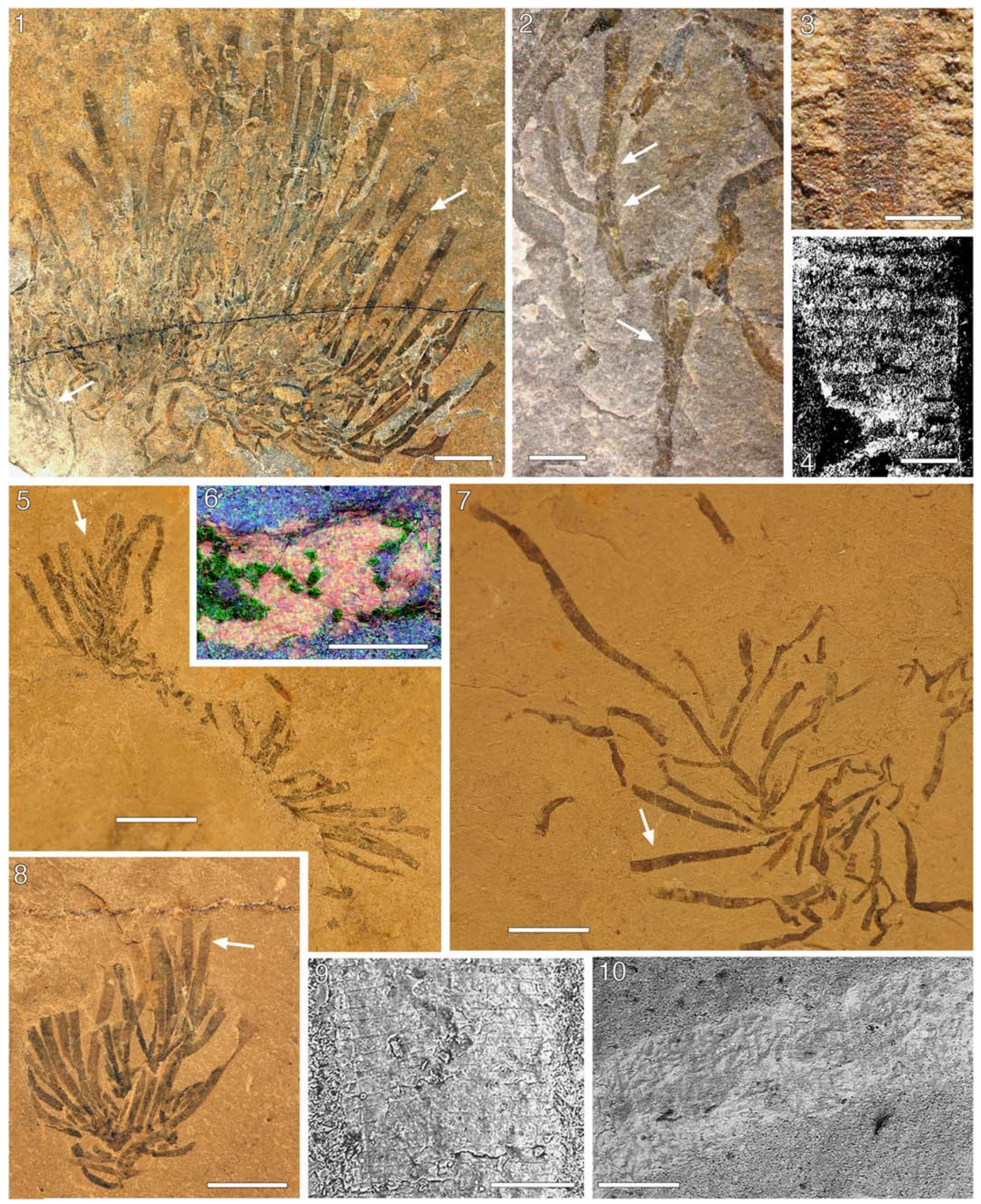
Table 2. Summary of EDS point spectral data for the two analyzed KUMIP specimens

\begin{tabular}{llllrrrrrrrrrrrrr}
\hline & Category & $\mathrm{N}$ & $\mathrm{O}$ & $\mathrm{Fe}$ & $\mathrm{Si}$ & $\mathrm{Al}$ & $\mathrm{Mg}$ & $\mathrm{C}$ & $\mathrm{K}$ & $\mathrm{Ca}$ & $\mathrm{S}$ & $\mathrm{Ti}$ & $\mathrm{Na}$ & $\mathrm{P}$ & $\mathrm{Mn}$ \\
\hline Spence Fm & Rock & 13 & 53.6 & 4.3 & 18.4 & 10.4 & 2.1 & 3.8 & 5.1 & 1.2 & 0.4 & 0.6 & 0 & 0 & 0 \\
314270 & Fossil & 17 & 51.4 & 17.6 & 10.7 & 9.4 & 5.8 & 2.7 & 1.3 & 0.8 & 0.2 & 0 & $<0.1$ & $<0.1$ & 0 \\
Wheeler Fm & Rock & 28 & 51.6 & 6.6 & 18.8 & 9.9 & 2.1 & 3.7 & 4.4 & 2.4 & 0.2 & 0.4 & $<0.1$ & 0 & 0 \\
314068 & Fossil & 43 & 47.2 & 17.6 & 11.7 & 8.7 & 4.1 & 6.6 & 1.7 & 2.2 & 0.1 & $<0.1$ & $<0.1$ & 0 & $<0.1$ \\
\hline
\end{tabular}

All elemental point data reported in normalized weight percentage and organized, from left to right, by general abundance in fossil material.

technique was used to emphasize the "Yuknessia" part but the "Dalyia" part remained unaltered and is not visible.

In images of USNM 35408 taken under polarized light it is clear that several of the stipes do indeed branch, resulting in terminal whorls comprising cylindrical elements. This specimen also differs from the $Y$. simplex holotype in that the stipes maintain a constant width along their length and show no evidence of transverse striations in BSE images, instead presenting a structureless surface essentially identical to that observed in the present study for a specimen of Dalyia racemata (USNM 35416, also from the Phyllopod Bed interval at the Walcott Quarry site). Collectively, the features presented by USNM 35408 permit unambiguous identification as $D$. racemata (see particularly Walcott, 1919, plate 56, figure $1 \mathrm{~b}$ ), and it is herein formally transferred to this taxon.

As noted by Walcott (1919), the gross morphology of Dalyia is consistent with an algal affinity. The appearance of this material in BSE images does not alter this view. Thallus architecture, however, permits either a red or green affinity and, lacking details with regard to pigment type, cellular organization, and reproduction, Walcott's (1919) assignment of Dalyia to the Rhodophyta is herein regarded as uncertain.

Algae incertae sedis

Figure 1.5-1.7

Referred Material._-USNM 35407.

Description.-Thallus for USNM 35407 comprises numerous narrow elongate elements that radiate outward from a small central area to form a rosette roughly $10 \mathrm{~mm}$ in diameter. Central area (holdfast?) slightly raised, roughly circular in form, with a diameter of approximately $1 \mathrm{~mm}$ (Fig 1.5). Elongate elements flat, unbranched, with a rectilinear form and characterized by a darker black color, smother texture, and glossier luster than the shale matrix; most 2 to $3 \mathrm{~mm}$ in length, some as short as $1 \mathrm{~mm}$, the longest reaching $5 \mathrm{~mm}$; overall form difficult to discern in all cases, but the longest clearly gently taper distally from an average width at mid-length of $0.093 \mathrm{~mm}$ to a distal width of $0.04 \mathrm{~mm}$ $(\mathrm{SD}=0.009 \mathrm{~mm}, \mathrm{~N}=10$ ) (Fig. 1.6). Fine longitudinal ridges evident in BSE images (Fig 1.7).
Remarks.-The other of Walcott's two $Y$. simplex paratypes, USNM 35407, like 35408, differs markedly from the holotype in several key respects regarding the morphology of the elongate elements. Here, maximum length and width, respectively, are only one-third and one-fourth those for the holotype. Overall form for these structures differs as well, these in some cases clearly tapering distally instead of expanding, and BSE images show no evidence of transverse striations. Based on these differences, 35407 is formally removed from Yuknessia. This specimen in some respects resembles the associated cyanobacterium Marpolia Walcott, 1919, which can form radiating clumps of filaments, these showing fine longitudinal ridges in BSE images very similar to those observed for 35407 (Handle and Powell, 2012; fig. 4G), but the elongate elements for 35407 appear stiffer and somewhat wider. Pending additional information, this specimen is regarded herein broadly as an alga of uncertain affinity. Because the photographs in Walcott's 1919 report are retouched, the elongate elements appear wider and of somewhat different form in the only figure of 35407 in that report (pl. 54, fig. 1b).

\section{Elemental composition of Utah Yuknessia}

To investigate original composition for Yuknessia, EDS analysis was applied to two Utah specimens, KUMIP 314068 from the Wheeler Shale and KUMIP 314270 from the Spence Shale. For 314068, EDS point analysis, summarized in Table 2, indicates that carbon comprises a minor component of the fossil. In EDS elemental maps of the fossil surface, carbon is concentrated in disseminated but abundant small patches (in green in Fig. 5.6). These patches correspond to relatively dark gray areas in BSE images and to conspicuous black areas in reflected light that often form a thin surficial crust (Fig. 5.5). In contrast, iron content is high throughout the fossil. For areas of the fossil surface between carbon patches, EDS elemental maps show a strong iron signal (Fig. 5.6). Corresponding areas appear relatively bright in BSE images and orangish-brown in reflected light (Fig. 5.5). Both the host rock and the iron-rich parts of the fossil show an apparent aluminosilicate composition. Relative to the host rock, the fossil yields elevated levels of magnesium in addition to iron, and reduced levels of potassium and silicon, indicating a clay mineralogy for the fossil distinct from the host

\footnotetext{
Figure 5. Yuknessia stephenensis n. sp. from Utah: (1), KUMIP 204381, entire specimen, Spence Shale, Wellsville Mountains; (2), enlargement of repent portion of colony at lower arrow in 1, branching points marked by arrows; (3), enlargement of erect tube at upper arrow in 1 showing fusellar structure; (4), BSE image of lower part of tube shown in 3; (5), KUMIP 314068, entire specimen, Wheeler Shale, Drum Mountains; (6), EDS elemental map (red = iron, blue = silicon, green $=$ carbon) overlain on secondary electron micrograph for tube indicated by arrow in $\mathbf{5}$, green and red areas correspond to areas that are black and brown, respectively, on the fossil; (7), KUMIP 314270, entire specimen, Spence Shale, Wellsville Mountains; (8), FMNH PE 61080, entire specimen, Pierson Cove Formation, Drum Mountains; (9), BSE image of erect tube marked by arrow in $\mathbf{8}$ showing fusellar structure; (10), BSE image of erect tube marked by arrow in $\mathbf{7}$ showing fusellar structure. All non-BSE images show dry specimens in direct light. Scale bars: 1, 5, 7, 8, 5 mm; 2, 3, $1 \mathrm{~mm} ; \mathbf{4}, \mathbf{9}, 0.2 \mathrm{~mm} ; \mathbf{6}, 0.35 \mathrm{~mm} ; \mathbf{1 0}, 0.5 \mathrm{~mm}$.
} 
rock. Owing to $\mu \mathrm{m}$-scale spatial elemental heterogeneities in the fossil and host rock material, however, precise mineralogical identification is not possible on the basis of EDS analysis alone, although the mean fossil aluminosilicate composition is not inconsistent with iron-rich smectite or chlorite group clays. For 314270 , EDS point analysis indicates a composition similar to 314068 , but here carbon content for the fossil is lower and is essentially identical to the host rock (Table 2). No black patches are evident on this specimen in reflected light (Fig. 5.7).

Handle and Powell (2012), using EDS and WDS (wavelength dispersive X-ray spectroscopy) elemental mapping, also examined elemental composition for a Utah Yuknessia specimen (identified in their study as KUMIP 314270 from the Spence Shale but the associated figures 2D and 4A show KUMIP 147909 from the Wheeler Shale). In addition to an iron-rich composition, they reported that carbon was a major component of the specimen. When combined with the present results, this points to a wide range in carbon content between specimens of Yuknessia. Compositional differences in this regard may be correlative to the extent of weathering, consistent with the orangish-brown color of the fossils. It is also possible that this is dependent on whether the part or counterpart of the same specimen is being studied. For example, for non-biomineralizing fossils from the Burgess Shale, the carbonaceous layer often separates from its aluminosilicate replicate along the plane of split and is more abundant on one side than the other (see text-fig. 1 B-D in Butterfield et al., 2007). The present results confirm that areas of Utah Yuknessia specimens with organic preservation can be identified on the basis of color. As a result, it can be confidently inferred that KUMIP 204382, characterized by a dark gray to black color in reflected light (Fig. 4.4), has organic preservation throughout, and that organic preservation for KUMIP 204380 is limited to scattered black patches (Fig. 3.1, 3.4).

Considered collectively, elemental composition for the tubes of Yuknessia is consistent with an originally organic composition. Similar elemental compositions have been documented for non-biomineralizing fossils from Burgess Shale-type deposits, the material being preserved as carbonaceous compressions but including replication by clay minerals and overprinting by pyrite (e.g., Orr et al., 1998, 2009; Gabbott et al., 2004; Hu, 2005; Zhu et al., 2005; Butterfield et al., 2007; Gaines et al., 2008; Page et al., 2008; Anderson et al., 2011; Cai et al., 2012; Meyer et al., 2012; Schiffbauer et al., 2014). The Utah material, however, seems to show a stronger iron overprint than non-biomineralized Burgess Shale material.

\section{Comparisons}

Yuknessia, as redescribed herein, closely resembles living rhabdopleurid pterobranchs, all of which are assigned to Rhabdopleura, in that the tubaria comprise interconnected repent and erect tubes with distinct growth bands (fusellae) and oblique sutures. Rhabdopleura tubaria are composed of organic material and, as noted above, the same can be inferred for Yuknessia colonies. In addition, Rhabdopleura produces new tubes from repent tubes by perforation of the lateral wall of the parent tube, as opposed to budding at the aperture, and the same is evident for Yuknessia. Although runner-type colonies are most common for Rhabdopleura, in $R$. compacta, as in
Yuknessia, the repent part of the colony is greatly reduced. Finally, for living rhabdopleurids distinct fusellar collars are present on the erect tubes, and these may correspond to the ridges noted on some Yuknessia specimens, although in this case other interpretations are possible (e.g., localized thickening of the tube wall), and this morphology is lacking on most specimens. Despite the noted similarities, however, living rhabdopleurids differ from Yuknessia with regard to several important aspects, including a distinct zig-zag suture pattern on the repent tubes and a lack of branching for the erect tubes. For these reasons, Yuknessia is maintained as a separate genus. Rhabdopleura also has a stolon system that appears to be lacking in Yuknessia. The absence of this key feature in Yuknessia, however, is regarded to reflect the lack of a sclerotized sheath for the stolon system, as has been documented for other early colonial pterobranchs (reviewed in Mitchell et al., 2013), rather than the actual absence of a stolon.

Yuknessia bears a striking degree of similarity to several Cambrian taxa described as early benthic pterobranchs. Material assigned to Rhabdopleura obuti by Durman and Sennikov (1993) from the middle Cambrian of Siberia closely resembles Yuknessia stephenensis in terms of the general shape (conical) and size (average length $6.6 \mathrm{~mm}$; aperture width up to $1.25 \mathrm{~mm}$ ) for the erect tubes, and details of fusellar arrangement (fusellar height $0.05-0.1 \mathrm{~mm}$ for the erect tubes and lacking obvious zig-zag suture pattern on the stolonal tubes). Colony construction and organization are also similar. This taxon differs from $Y$. stephenensis in having a sclerotized stolon sheath and more frequent branching of the erect tubes. The taxonomic significance of these distinctions, however, is unclear, and further study may prove the two species to be congeneric. Maletz et al. (2005), while supporting a benthic colonial pterobranch affinity for $R$. obuti, removed the taxon from Rhabdopleura because the repent tubes lack a distinct zig-zag suture and the erect tubes widen distally and branch, characteristics that also apply to Yuknessia.

Material from the Cambrian of Sweden described as Rhabdotubus johanssoni by Bengtson and Urbanek (1986) resembles Yuknessia stephenensis in terms of general shape and size for the erect tubes (up to $10 \mathrm{~mm}$ long and $1 \mathrm{~mm}$ wide at the aperture), details of fusellar arrangement (fusellar height $0.06-0.1 \mathrm{~mm}$ for the erect tubes and only rarely visible oblique sutures), and lack of an evident stolon, which was attributed by Bengtson and Urbanek (1986) to a lack of a sclerotized stolon sheath rather than the actual absence of a stolon system, a viewpoint followed in this report for Yuknessia. General colony form is also similar in that the repent area is small and the erect tubes form a radiating pattern with lower parts in some cases being adnate. According to Bengtson and Urbanek (1986), the tubes are interconnected, but this aspect was regarded as uncertain by Maletz et al. (2005) and Maletz (2014). A key difference between this material and all specimens assigned to Yuknessia herein is the presence of a distinct ventral lip on the aperture, an element incorporated in the diagnosis for Rhabdotubus (Bengtson and Urbanek, 1986, p. 296). No evidence for such an elaboration of the aperture is present among any of the Yuknessia material, and on this basis the material described herein as $Y$. stephenensis is not regarded as congeneric with the Swedish material despite being similar in other respects. With regard to $Y$. simplex, the Swedish material clearly differs by the greater width 
of the tubes, but a notable point in common is that specimens from both occurrences are attached to foreign objects, albeit those for the latter are clearly brachiopod shells whereas this is not the case for the British Columbia material. Rickards and Durman (2006) determined that $R$. johanssoni is a junior synonym of Fasciculitubus tubularis Obut and Sobolevskaya, 1967, a taxon erected on the basis of material from the Cambrian of Siberia. Although the emended diagnosis for Fasciculitubus provided by Rickards and Durman (2006) indicates a ventral lip for the aperture, they described the aperture of the Siberian material of $F$. tubularis as simple. In this regard, it resembles Yuknessia, with which it also shares similar dimensions for the erect tubes in the case of $Y$. stephenensis. The repent part of $F$. tubularis, however, is poorly known and fusellar structure is not known for any specimens. Pending further information about these key aspects, Yuknessia is maintained as a separate taxon.

Material described by Maletz et al. (2005) as Rhabdotubus robustus Maletz, Steiner, and Fatka, 2005 from the middle Cambrian of Konícek and Luh in the Czech Republic resembles Yuknessia stephenensis in terms of general shape and size for the erect tubes (up to $10 \mathrm{~mm}$ long and $1.5 \mathrm{~mm}$ wide at the aperture) and details of fusellar arrangement (fusellar height $0.07-0.13 \mathrm{~mm}$ for the erect tubes). This taxon differs from both yuknessid taxa by having an extensive repent part for the colony up to $1 \mathrm{~mm}$ wide and several centimeters in length. In addition, specimens show clear evidence of a stolon and lack branching of the erect tubes.

Other early Paleozoic hemichordates that merit comparison to Yuknessia include dithecoid and tuboid graptolites. With regard to dithecoid graptolites (sensu Rickards and Durman, 2006), Yuknessia bears some similarity to Archaeolafoea Chapman, 1919. Archaeolafoea monegettae (Chapman, 1919), which occurs in direct association with $Y$. stephenensis in the Wheeler Shale (LoDuca and Kramer, 2014), has free (lateral) thecae that compare closely with the erect tubes of $Y$. stephenensis in terms of overall form (conical), size (up to $9 \mathrm{~mm}$ long and $0.7 \mathrm{~mm}$ wide at the aperture), and details of fusellar arrangement (infrequent oblique sutures and a fusellar height of 0.013-0.022 mm). In similar fashion the free thecae of A. fruticosa Chapman and Thomas, 1936 compare closely with the erect tubes of $Y$. simplex from the Trilobites Beds, and a dithecoid graptolite has been reported from a slightly younger Burgess Shale-type deposit about $50 \mathrm{~km}$ southeast of Mount Stephen (Johnston et al., 2009). Archaeolafoea and other dithecoid graptolites, however, differ in the development of a prominent elongate central axis, and definitive evidence of such a structure is lacking in all material assigned herein to Yuknessia. New specimens ROM 62920 and 62921 from the Trilobite Beds do have an orientation and arrangement for the erect tubes highly reminiscent of Archaeolafoea colonies, and the possibility that an axis is concealed beneath the tubes cannot be eliminated by the evidence at hand. Notably, R. obuti also occurs with Archaeolafoea in the middle Cambrian of Siberia (Durman and Sennikov, 1993, p. 284), suggesting that these different pterobranch groups commonly occurred in association in the Cambrian biosphere. Tuboid graptolites can have zooidal tubes with a form similar to the erect tubes of Yuknessia. In this case, however, the zooidal tubes are characterized by distinct thecal dimorphism (autothecae and bithecae) (Maletz et al.,
2005; Mitchell et al., 2013), and no evidence of such a condition is present for Yuknessia.

\section{Conclusions}

New features revealed by SEM examination, in combination with detailed comparative study, indicate that Yuknessia is an early benthic colonial pterobranch and not an alga as originally described. It differs sufficiently from other fossil and living pterobranchs to be maintained as a separate genus, but interpretation of broader-scale relationships within the Pterobranchia must await treatment of this and similar Cambrian taxa within a comprehensive phylogenetic analysis similar to that recently conducted by Mitchell et al. (2013), the outcome of which indicates that living rhabdopleurids nest within the graptolite clade.

Yuknessia specimens from the Trilobite Beds of British Columbia and the Spence Shale of Utah are the first hemichordates reported from these units and are amongst the oldest known examples of colonial pterobranchs. A colonial habit for older pterobranch material described from the Chengjiang Biota (Series 2) and the Kaili Formation of China (basal Stage 5) is uncertain as the material comprises isolated tubes which may be fragments of larger specimens (Hou et al., 2011; Harvey et al., 2012), and possible rhabdopleurids from the Niutitang Formation of China (Series 2) figured by Zhao et al. (1999) require further study to firmly establish a pterobranch affinity. Yuknessia is one of two hemichordate taxa currently regarded to occur within the Wheeler Shale, the other being the recently reported dithecoid graptolite Archaeolafoea monegettae, and it is the third such taxon reported from the Burgess Shale biota, along with Chaunograptus Ruedemann, 1931 and Spartobranchus (Walcott, 1911) from the Phyllopod Bed, the latter recently redescribed as a tubicolous enteropneust (Caron et al., 2013). The presence from the Cambrian Stage 5 onwards of a range of colonial pterobranchs in marine benthic environments worldwide provides evidence that the postulated divergence of pterobranchs from a tubular enteropneust ancestor and subsequent miniaturization (Caron et al., 2013) would have been achieved early on during the Cambrian.

Findings reported herein indicate that specimens attributed to Yuknessia from the Kinzers Formation of Pennsylvanian and the Cambrian of China require restudy to confirm such an affinity. In broader terms, the results of this study point to the need for SEM-based studies of other Cambrian material previously described as noncalcified macroalgae to resolve the early evolutionary histories of both hemichordates and macrophytes.

\section{Acknowledgments}

We thank D. Cooper and M. Phillips for donating the $Y$. stephenensis specimen from the Pierson Cove Formation. ROM specimens were collected under several Parks Canada research and collection permits delivered to D. Collins. Assistance with electron microscopy was provided by L. Hayden, Y. Chen, and G. Moore (University of Michigan), S. Whittaker and C. Baker (Smithsonian Institution), and G. Kretschmann (University of Toronto). K. Marsac also assisted with electron microscopy at the University of Michigan and Smithsonian. 
Work on this project by S. L. was funded in part by the National Science Foundation (EAR 1250756), D. Cooper, and the College of Arts and Sciences and Graduate School at Eastern Michigan University. J.-B. C. acknowledges support from a Natural Sciences and Engineering Research Council of Canada Discovery Grant (\#341944). J. D. S. acknowledges support from the Virginia Tech Nanoscale Characterization and Fabrication Laboratory and the Mizzou Electron Microscopy Core. Work by S. X. was funded in part by NSF grant EAR 1250800 . Field work in Utah by A. K. was assisted by S. Halgedahl and R. Jarrard. Study of museum material was facilitated by D. Erwin, K. Hollis, M. Florence, B. Lieberman, and Ú. Farrell. Reviews by M. Melchin and an anonymous reviewer and comments by editor B. Pratt substantially improved the manuscript. This is Royal Ontario Museum Burgess Shale project number 57.

\section{References}

Anderson, E.P., Schiffbauer, J.D., and Xiao, S., 2011, Taphonomic study of organic-walled microfossils confirms the importance of clay minerals and pyrite in Burgess Shale-type preservation: Geology, v. 39, p. 643-646.

Babcock, L.E., Peng, S., Wasserman, G.J., and Robison, R.A., 2011, Exceptionally preserved biota from a carbonate lithofacies, Huaqiao Formation (Cambrian: Drumian Stage), Hunan, China: Memoirs of the Association of Australasian Palaeontologists, v. 42, p. 137-151.

Babcock, L.E., and Zhang, W.T., 2001, Stratigraphy, paleontology, and depositional setting of the Chengjiang Lagerstätte (lower Cambrian), Yunnan, China, in Peng, S.C., Babcock, L.E., and Zhu, M.Y. eds., Cambrian of South China: Hefei, University of Science and Technology of China Press, p. 66-86.

Bateson, W., 1885, The later stages in the development of Balanoglossus kowalevskii, with a suggestion as to the affinities of the Enteropneusta: Quarterly Journal of the Microscopical Society, v. 25, p. 81-122.

Bengtson, S., and Urbanek, A., 1986, Rhabdotubus, a Middle Cambrian rhabdopleurid hemichordate: Lethaia, v. 19, p. 293-308.

Butterfield, N.J., Balthasar, U., and Wilson, L.A., 2007, Fossil diagenesis in the Burgess Shale: Palaeontology, v. 50, p. 537-543.

Cai, Y., Schiffbauer, J.D., Hua, H., and Xiao, S., 2012, Preservational modes in the Ediacaran Gaojiashan Lagerstätte: Pyritization, aluminosilicification, and carbonaceous compression: Palaeogeography, Palaeoclimatology, Palaeoecology, v. 326-328, p. 109-117.

Caron, J.-B., Conway Morris, S., and Cameron, C.B., 2013, Tubicolous enteropneusts from the Cambrian period: Nature, v. 495, p. 503-506.

Caron, J.-B., and Jackson, D.A., 2006, Taphonomy of the Greater Phyllopod Bed community, Burgess Shale: Palaios, v. 21, p. 451-465.

Caron, J.-B., and Jackson, D.A., 2008, Paleoecology of the Greater Phyllopod Bed community, Burgess Shale: Palaeogeography, Palaeoclimatology, Palaeoecology, v. 258, p. 222-256.

Chapman, F., 1919, On some hydroid remains of lower Palaeozoic age from Monegetta, near Lancefield: Proceedings of the Royal Society of Victoria, v. 31, p. 388-393.

Chapman, F., and Thomas, D.E., 1936, The Cambrian Hydroida of the Heathcote and Monegeeta districts: Proceedings of the Royal Society of Victoria, v. 48 , p. 193-219.

Chen, J.Y., and Erdtmann, B.D., 1991, Lower Cambrian fossil Lagerstätte from Chengjiang, Yunnan, China: insights for reconstructing early metazoan life, in Simonetta, A.M. and Conway Morris, S. eds., The Early Evolution of Metazoa and the Significance of Problematic Taxa, Cambridge, Cambridge University Press, p. 57-75.

Chen, J.Y., Zhou, G.Q., Zhu, M.Y., and Yeh, K.Y., 1996, The Chengjiang Biota: A Unique Window of the Cambrian Explosion, Taichung, National Museum of Natural Science, $222 \mathrm{p}$.

Conway Morris, S., and Robison, R.A., 1988, More soft-bodied animals and algae from the Middle Cambrian of Utah and British Columbia: The University of Kansas Paleontological Contributions, v. 122, p. 1-48.

Durman, P.N., and Sennikov, N.V., 1993, A new rhabdopleurid hemichordate from the Middle Cambrian of Siberia: Palaeontology, v. 36, p. 283-296.

Fletcher, T.P., and Collins, D.H., 1998, The Middle Cambrian Burgess Shale and its relationship to the Stephen Formation in the southern Canadian Rocky Mountains: Canadian Journal of Earth Sciences, v. 35, p. 413-436.
Fu, X., Wu, M., Liu, X., Peng, J., and Zhao, Y., 2010, Macroalgae from the Balang Formation of the Duyunian (Cambrian), Guizhou Province: Acta Micropalaeontologica Sinica, v. 27, p. 231-241.

Gabbott, S.E., Hou, X.G., Norry, M.J., and Siveter, D.J., 2004, Preservation of Early Cambrian animals of the Chengjiang biota: Geology, v. 32, p. 901-904.

Gaines, R.R., Briggs, D.E.G., and Zhao, Y., 2008, Cambrian Burgess Shale-type deposits share a common mode of fossilization: Geology, v. 36, p. 755-758.

Guo, J., Li, Y., and Shu, D., 2010, Fossil macroscopic algae from the Yanjiahe Formation, Terreneuvian of the Three Gorges area, South China: Acta Palaeontologica Sinica, v. 49, p. 336-342.

Handle, K.C., and Powell, W.G., 2012, Morphologically simple enigmatic fossils from the Wheeler Formation: A comparison with definitive algal fossils: Palaios, v. 27, p. 304-316.

Harvey, T.H.P., Ortega-Hernández, J., Lin, J.-P., Zhao, Y., and Butterfield, N.J., 2012, Burgess Shale-type microfossils from the middle Cambrian Kaili Formation, Guizhou Province, China: Acta Palaeontologica Polonica, v. 57, p. $423-436$.

Hou, X.G., Aldridge, R.J., Siveter, D.J., Siveter, D.J., Williams, M., Zalasiewicz, J. and Ma, X.Y., 2011, An early Cambrian hemichordate zooid: Current Biology, v. 21, p. 612-616.

Hou, X.G., Bergström, J., Wang, H.F., Feng, X.H., and Chen, A.L., 1999, The Chengjiang Fauna: Exceptionally Well-Preserved Animals from 530 Million Years Ago, Kunming, Yunnan Science and Technology Press, $170 \mathrm{p}$.

Hu, S., 2005, Taphonomy and Paleoecology of the Early Cambrian Chengjiang Biota from Eastern Yunnan, China, Band 7: Berliner, Berliner Paläobiologische Abhandlungen, 197 pp.

Johnston, K.J., Johnston, P.A., and Powell, W.G., 2009, A new, Middle Cambrian, Burgess Shale-type biota, Bolaspidella Zone, Chancellor Basin, southeastern British Columbia: Palaeogeography, Palaeoclimatology, Palaeoecology, v. 277, p. 106-126.

Lankester, E.R., 1877, Notes on the embryology and classification of the animal kingdom, p. comprising a revision of speculations relative to the origin and significance of the germ-layers: Quarterly Journal of Microscopical Science, v. 68 , p. $399-454$.

LoDuca, S. T., and Kramer, A., 2014, Graptolites from the Wheeler and Marjum formations (Cambrian: Series 3) of Utah: Journal of Paleontology, v. 88 p. $403-410$.

Maletz, J., 2014, Hemichordata (Pterobranchia, Enteropneusta) and the fossil record: Palaeogeography, Palaeoclimatology, Palaeoecology, v. 398, p. 16-27.

Maletz, J., Steiner, M., and Fatka, O., 2005, Middle Cambrian pterobranchs and the question: What is a graptolite? Lethaia, v. 38, p. 73-85.

Meyer, M., Schiffbauer, J.D., Xiao, S., Cai, Y., and Hua, H., 2012, Taphonomy of the late Ediacaran enigmatic ribbon-like fossil Shaanxilithes: Palaios, v. 27, p. 354-372.

Mitchell, C., Melchin, M., Cameron, C., and Maletz, J., 2013, Phylogenetic analysis reveals that Rhabdopleura is an extant graptolite: Lethaia, v. 46, p. 34-56.

Obut, A.M., and Sobolevskaya, R.F., 1967, Some stereostolonates of the Late Cambrian and Ordovician of the Norilsk region, in Ivanovsky, A.B. and Sokolov, B.S. eds., New Data on Biostratigraphy of the Lower Palaeozoic of the Siberian Platform. Akademia Nauk SSR, Sibirskoe otdelenie, Institut geologii i geofiziki, p. 45-64 (In Russian).

Orr, P.J., Briggs, D.E.G., and Kearns, S.L., 1998, Cambrian Burgess Shale animals replicated in clay minerals: Science, v. 281, p. 1173-1175.

Orr, P.J., Kearns, S.L., and Briggs, D.E.G., 2009, Elemental mapping of exceptionally preserved 'carbonaceous compression' fossils: Palaeogeography, Palaeoclimatology, Palaeoecology, v. 277, p. 1-8.

Page, A., Gabbott, S.E., Wilby, P.R., and Zalasiewicz, J.A., 2008, Ubiquitous Burgess Shale-style "clay templates" in low-grade metamorphic mudrocks: Geology, v. 36, p. 855-858.

Rickards, B., and Durman, P.N., 2006, Evolution of the earliest graptolites and other hemichordates, in Bassett, M.G. and Deisler, V.K., eds., Studies in Palaeozoic Palaeontology: Cardiff, UK, National Museum of Wales, Geological Series, 25, p. 5-92.

Ruedemann, R., 1931, Some Middle Cambrian fossils from British Columbia: Proceedings of the United States National Museum, v. 79, p. 1-18.

Satterthwait, D.F., 1976, Paleobiology and paleoecology of Middle Cambrian algae from western North America. Unpublished Ph.D. dissertation, University of California, Los Angeles, $121 \mathrm{p}$.

Schiffbauer, J.D., Xiao, S., Cai, Y., Wallace, A.F., Hua, H., Hunter, J., Xu, H., Peng, Y. and Kaufman, A.J., 2014, A unifying model for NeoproterozoicPalaeozoic exceptional fossil preservation through pyritization and carbonaceous compression: Nature Communications, DOI: 10.1038/ ncomms6754.

Skinner, E., 2005, Taphonomy and depositional circumstances of exceptionally preserved fossils from the Kinzers Formation (Cambrian), southeastern Pennsylvania: Palaeogeography, Palaeoclimatology, Palaeoecology, v. 220, p. $167-192$. 
Stebbing, A.R.D., 1970, The status and ecology of Rhabdopleura compacta (Hemichordata) from Plymouth: Journal of the Marine Biological Association of the United Kingdom, v. 50, p. 209-221.

Walcott, C.D., 1911, Cambrian Geology and Paleontology II: Middle Cambrian annelids: Smithsonian Miscellaneous Collections, v. 57, p. 109-145.

Walcott, C.D., 1919, Cambrian Geology and Paleontology IV, no. 5 Middle Cambrian algae: Smithsonian Miscellaneous Collections, v. 67, p. 217-260.

Yang, R.-D., 2006, Study on Algae Fossils and Palaeoecology of Kaili Biota, Guizhou Province: Guiyang, Guizhou Science and Technology Press, 186 p. (In Chinese with English summary).

Yang, R.-D., Zhao, Y., and Guo, Q.-J., 1999, Algae and acritarchs and their palaeooceanographic significance from the early Cambrian black shale in Guizhou, China: Acta Palaeontologica Sinica, v. 38, p. 146-156 (In Chinese with English summary).

Yang, R.-D., Zhang, W., Jiang, L., and Gao, H., 2003, Members of the Chengjiang Biota from the Lower Cambrian Niutitang Formation, Zunyi County, Guizhou Province, China: Acta Geologica Sinica, v. 77, p. $145-150$ (In Chinese).
Zhao, Y., Steiner, M., Yang, R.-D., Erdtmann, B.-D., Guo, Q. J., Zhou, Z., and Wallis, E., 1999, Discovery and significance of the early Metazoan biotas from the Lower Cambrian Niutitang Formation, Zunyi, Guizhou: Acta Palaeontologica Sinica, v. 38, p. 132-144 (Supplement).

Zhao, Y., Zhu, M.Y., Babcock, L.E., Yuan, J.L., Parsley, R.L., Peng, J., Yang, X., and Wang, Y., 2005, The Kaili Biota: A taphonomic window on diversification of metazoans from the basal middle Cambrian, Guizhou, China: Acta Geologica Sinica, v. 79, p. 751-765.

Zhao, Y., Zhu, M.Y., Babcock, L.E., and Peng, J., 2011, The Kaili Biota: Marine Organisms from 508 Million Years Ago: Guiyang, Guizhou University Press (In Chinese). $251 \mathrm{p}$

Zhu, M.Y., Babcock, L.E., and Steiner, M., 2005, Fossilization modes in the Chengjiang Lagerstätte (Cambrian of China): testing the roles of organic preservation and diagenetic alteration in exceptional preservation: Palaeogeography, Palaeoclimatology, Palaeoecology, v. 220, p. 31-46.

Accepted 4 July 2014 